ISSN: $2146-3042$

DOI: $10.25095 /$ mufad.605919

\title{
Yap-İşlet-Devret İle Yapılan Havalimanı Yatırımları Üzerine Bir Değerlendirme*
}

\author{
Bülent TOPDEMIR ${ }^{* *}$ \\ Murat AZALTUN ${ }^{* * *}$
}

\section{ÖZET}

Dünya ve Türkiye'de yeni yapılan havalimanlarında ve mevcut havalimanlarına yapılan yatırımlarda kamu ve özel sektörün birlikte hareket etmesi ve finansman ihtiyaçlarının özel sektör tarafindan karşılanması devletlerin üstündeki bütçe baskısını azalmıştır. Türkiye'nin en önemli kurumlarından birisi olan DHMI tarafindan gerçekleştirilen Yap İşlet Devret (YID) modelinde yatırım için hiçbir maddi kaynak ayrılmadan yapılması hatta bazı modellerde üzerine kira alınması dolayısıyla genelde başarılı sonuçlar alındığı söylenebilir. Ancak, Türkiye'nin beş büyük ilindeki havalimanına ilişskin ihale verileri incelendiğinde terminal yatırımlarının parasal değeri, havalimanı ciro ve FAVÖK tutarlarına göre düşük kalmaktadır. Çalışmanın amacı Türkiye'deki büyük havalimanlarının YID modeli ile yapımı ve işletilmesinin kamu menfaati açısından değerlendirilmesidir. Çalışmanın metodu Türkiye'nin en üç büyük havalimanlarındaki YID modelinin yatırım tutarl, garanti yolcu sayıları, gerçekleşen ve gerçekleşmesi öngörülen ciro ve FAVÖK'ün analizi yapılarak her bir ihalenin mali sonuçlarının incelenmesidir. Çalışmada tamamen özel sektöre bırakılan işletmeciliğin yerine, belirlenecek bir oranda kamunun ortak edilmesi önerilmiştir. Bu sayede kamu tarafinın daha fazla kontrol gücünü elinde tutacağl, ayrica tahmin edilenin üzerinden oluşacak karlardan ve değerlenen şirketlerin getirilerinden kamunun pay almasının sağlanabileceği ifade edilmiştir. Ayrıca kırılganlıklarda oluşacak zararların bir kısmına kamunun katılmasının mümkün olabileceği tespiti yapılmıştır.

Anahtar Kelimeler: Kamu Hizmeti, Havalimanı, Кати Özel Ortaklı̆̆l, Mali Analiz.

JEL Sinıflandirmast: M40, M41, M49.

\section{An Assessement On Buld-Operate-Transfer (Bot) Model Airport Investments}

\section{ABSTRACT}

Cooperation between the public and private sectors for building new airports and investing in the existing airports are financed by the private sector relieves the budget pressure on the governments. Developed by one of the most important institutions of Turkey, DHMI, the model BOT can be considered successful since not only it does not require any financial resources but also, in some cases, it even generates rental income for some projects. However, examining the bidding data regarding the two major airports of Turkey indicates that the monetary value of the terminal investments is low with respect to the airport revenue and EBITDA analysis. The purpose of this study is to evaluate the construction and operation of big airports in Turkey via BOT model. The method is to study the investment amount of BOT model, the number of minimum passengers, existing and forecasted revenue, and EBITDA analyses regarding the two major airports in Turkey. Based on the study, it is proposed that the public sector should be involved in operations instead of leaving them to the private sector all together. Therefore, the public sector can have more control over operations as well as additional income due to higherthan-foreseen revenues. Moreover, the public sector can help with economic losses during economical instabilities.

Keywords: Public Service, Aviation, Build-Operate-Transfer Method, Financial Analysis.

Jel Classification: M40, M41, M49.

Makale Gönderim Tarihi: 01.06.2019

Makale Kabul Tarihi: 01.08.2019

Makale Türü: Araştırma Makalesi

* Çalışma Dr. Bülent Topdemir'in “Kamu Özel Ortaklığı Uygulamaları ve Havacılık Sektörüne Yönelik Bir Model Önerisi” başlıklı tezi kullanılarak hazırlanmıştır. Bu makale, 1-4 Mayıs 2019 tarihlerinde Bursa'da düzenlenen V. Uluslararası Muhasebe ve Finans Sempozyumu'nda özet bildiri olarak sunulmuştur.

** Dr., Okan Üniversitesi, Sosyal Bilimler Enstitüsü, bulent.topdemir@gmail.com, ORCID ID: 0000-0003-01758799 .

*** Prof., Yalova Üniversitesi, İktisadi ve İdari Bilimler Fakültesi, mazaltun@gmail.com, ORCID ID: 00000003-1892-3279. 


\section{GíRİş}

Kamu hizmetlerinin özel sektör eliyle yürütülmesinin sağlanması için geçmişten günümüze kadar birçok metot kullanılmıştır. Devlet bütçelerinin yetersizlikleri ve özel sektörün sağladığı avantajlar ile gündeme gelen kamu hizmetlerinin bir kısmının özel sektör tarafından yerine getirilmesi fikri, ilk olarak özelleştirme adı altında ortaya çıkmıştır. Ancak özelleştirilen kamu hizmetlerinin tamamen özel sektöre bırakılmasına getirilen eleştiriler ve hizmetlerin yürütülmesinde karşılaşılan problemlerden dolayı, kamu ve özel sektörün birlikte işin içinde olduğu daha efektif ve uygulanabilir bir yöntem olan Kamu Özel Sektör Ortaklıklarının en önemli metodu olan Yap İşlet Devret Modeli ortaya çıkmıştır.

Kamu özel ortaklıklarının kullanıldığı önemli alanlardan biri olan ulaşım sektörü, küreselleşme ve uluslararası ticaretin gelişmesi ile önemli bir konum kazanmıştır. Ulaştırma sektörüne olan yoğun talep daha fazla altyapı yatırımlarını ve bununla birlikte ciddi finansman ihtiyaçlarını beraberinde getirmiştir. İnsanların gün geçtikçe artan güvenlik, konfor ve özellikle hız konusundaki talepleri ulaştırma sektöründeki hava ulaşımını öne çıkarmış ve dünyada ciddi bir talep artışı yaratmıştır.

$\mathrm{Bu}$ çalışmada, yap işlet devret modeli kullanılan havalimanlarının mali analizleri yapılmıştır. İşletmecilik usulü olarak tamamen özel sektöre bırakılan yap işlet devret modelinin yerine, kurulacak görevli şirketlere belli bir oranda kamunun ortak olması ile devletin daha fazla katkı sağlayacağı iddia edilmektedir.

\section{KAMU ÖZEL ORTAKLIKLARI VE YAP-ISŞLT-DEVRET MODELI}

Kamu özel ortaklığı; bir yatırımın tasarlanması, finansman ihtiyacının sağlanması, yapılması ve işletilmesinin yanında, önceden yapımı tamamlanmış bir projenin yenilenmesi, kiralanması, geliştirilmesi, bakım onarımının yapılması ve işletilmesinde devlet elinin yanı sıra özel teşebbüsünde sahip olduğu çeşitli avantajları değerlendirerek katılımın sağlanması olarak tanımlanmaktadır (Yalçın, 2014: 109).

Avrupa Komisyonu tarafından yayımlanan Yeşil Kitap ise, kamu özel ortaklığını, bir alt yapının veya sağlanacak hizmetin finansmanını, inşaatını, tadilatını, yönetimini veya bakım veya onarımını sağlamak amacıyla kamu otoriteleriyle özel sektör arasında ortaklık yapılmasına ilişkin bir model olarak tanımlamıştır (Green Paper, 2004: 3).

Kamu özel ortaklıkları, kamu hizmetlerini ve özellikle ileri teknoloji ve yüksek finansman ihtiyacı gereken yatırımların yapılması amacıyla kamu ve özel teşebbüsler arasında kurulan ve bir sözleşmeye dayalı ilişkilerdir. (Emek, 2009: 7)

Wall'a göre (2013) kamu özel ortaklıkları ile kamu hizmetlerinin kalitesinin artmakta, daha ekonomik olarak hizmet verilmekte, ayrıca bu hizmetlerin verilmemesi ihtimaline karşı yeni bir model olarak değerlendirilmekte ve bu modellere olumlu bakılmaktadır. Yine bu modellerin uygulanması ve kamu bütçeleri üzerindeki yüklerin azaldığı ve verilen hizmet kalitesinin yükseldiği belirtmektedir. (7-8)

Tüm bu tanım ve açıklamalara göre kamunun temel amacı, özel sektörün fonunu kullanmak ve özel sektörün teknik ve kurumsal yeteneklerinden istifade etmektir. 
Türkiye'de hem kamu özel ortaklıklarındaki gelişmeler hem de havacılık sektörünün önemli ölçüde aşama kaydetmesi ile son yıllarda ciddi havalimanı yatırımları yapılmıştır. Türkiye'de son dönemde yapılmasına veya genişletilmesine karar verilen havalimanları ile terminal binalarının yapımında ve işletilmesinde kamu özel ortaklığı türlerinden biri olan yap işlet devret modeli kullanılmıştır. Havacılık sektörü 2000'li yıllarda tahminlerin ötesinde büyümeler kaydetmiş olmasının yanında, aynı zamanda krizlerden de en çok etkilenen sektörlerin başında gelmektedir.

Yerlikaya'ya (2002) göre, "YİD sistemi aslında bir finansman modelidir. Bu model, kamusal nitelikli yatırımların gerçekleştirilmesinde kamu finansmanın yetersiz kaldığ durumlarda kullanılmaktadır. Devletin ekonomi ve kamu hizmeti anlayışının değişmesi sonucunda söz konusu yatırım ve hizmetlerin gerçekleştirilmesinde özel sermayenin finansman sağlama olanağı doğmuştur. YİD, özel sermayenin sağladığı yatırım ve finansman karşılığında belirli bir süreliğine karı veya zararı kendine ait olmak üzere ilgili yatırımları işletmesine ve süre sonunda tüm yatırım ve tesislerin bedelsiz ve her türlü borçtan ari olarak ilgili kamu idaresine geçmesini sağlayan bir modeldir.” (27)

YİD modelinin kanunlar önündeki tanımı ise 3996 sayılı Bazı Yatırım ve Hizmetlerin Yap-İşlet-Devret Modeli Çerçevesinde Yaptırılması Hakkında Kanun'un 3. maddesinde şöyle yapılmıştır: Yap-İşlet-Devret modeli; ileri teknoloji ve yüksek maddi kaynak ihtiyacı duyulan projelerin gerçekleştirilmesinde kullanılmak üzere geliştirilen özel bir finansman modeli olup, yatırım bedelinin (elde edilecek kar dahil) sermaye şirketine veya yabancı şirkete, şirketin işletme süresi içerisinde ürettiği mal veya hizmetin idare veya hizmetten yararlananlarca satın alınması suretiyle ödenmesini ifade etmektedir.

\section{METODOLOJI}

$\mathrm{Bu}$ çalışmanın konusunu havacılık sektöründeki, terminal işletmecilik modelleri oluşturmaktadır. Kamu tarafından açılan ihaleler sonrasında terminal işletmecilikleri, yap işlet devret modeli ile özel sektöre bırakılmaktadır. Çalışmanın içeriğinde Türkiye'nin en fazla kullanılan beş büyük havalimanlarındaki yap işlet devret modellinin analizi yapılarak her bir ihalenin mali durumu incelenmiştir.

Türkiye'nin en fazla yolcu ağırlayan havalimanlarında, kamu tarafından ihalesi yapılarak oluşturulan YİD modelinin her birisi için ayrı ayrı mali sonuçlar hesaplanmıştır. 2017 yılına kadar gerçekleşen tutarları işletmecilerin faaliyet raporlarından alınmıştır. Faaliyet raporuna ulaşılamayan ihalelerde ve yıllarda, mevcut durumda ulaşılabilen faaliyet raporlarındaki oranlar kullanılmıştır. Sonraki yıllar için Tablo 1'deki büyüme tahminlerine göre hesaplamalar yapılmıştır. 2018 ve sonrasında oluşan tutarlar ise Tablo 2'deki faiz oranları ve Tablo 3'deki risk primi oranlarının toplamı ile 2017 yılına getirilmiştir.

\section{ANALIZLERIN VARSAYIMLARI}

Havacılık sektöründe bugüne kadar yapılan YID ve KIDD ihaleleri Savunma Sanayi Başkanlığı tarafından yapılan Sabiha Gökçen Havalimanının terminal ve mütemmimleri ihalesi hariç DHMİ tarafından yapılmıştır. Genellikle yapılan ihalelerin konusunu Sabiha Gökçen Havalimanı hariç havalimanlarının terminal binalarının yapımı ve işletimi veya sadece işletimi şeklinde olmuştur. Sabiha Gökçen Havalimanı ihalesinde ise terminal 
gelirlerinin yanı sıra, akaryakıt, yer hizmetleri ve kargo antrepo gelirleri ihale kapsamına dahil edilmiştir.

İhale şartnameleri ve sözleşmeler incelendiğinde en önemli unsurun yolcu servis gelirleri olduğu görülmektedir. Yolcu servis ücretleri havalimanlarında iç hat ve dış hat uçuşa göre değişkenlik göstermekte ve yalnızca havalimanını kullanan giden yolculardan tahsil edilmektedir. Yolcu servis ücretleri havayolları tarafından tespit edilen bilet fiyatları içindeki en önemli maliyet kalemlerinden biri olup, havayolu firmaları tarafindan terminal işletmecilerine ödenmektedir. Yolcu servis ücretleri, ihale şartnamelerinde belirlendikten sonra tarifelerdeki değişiklikler Ulaştırma Bakanlığı tarafından onaylanmaktadır. Terminal binalarının işletilmesi ihale ile devredilen havalimanlarının pist işletmeciliği ve seyrüsefer sistemleri DHMİ sorumluluğunda kalmıştır. Ayrıca DHMİ bu havalimanlarında meydan otoritesi olarak faaliyetlerini sürdürmektedir. Havalimanlarının yolcu servis ücretleri dışındaki en büyük gelir kalemleri kiralık alanlardan elde edilen kiralar ve kiracı firmaların ciroları üzerinden alınan komisyon bedellerinden oluşturmaktadır. Özellikle dış hatlar terminallerinde bulunan gümrüksüz satış mağazalarından (Duty Free) terminal işletmecileri ciddi gelirler elde etmektedir. İstanbul Atatürk, Ankara Esenboğa ve İzmir Adnan Menderes Havalimanları için TAV Havalimanları Holding A.Ş. tarafından yayımlanan faaliyet raporlarındaki bilgilerden faydalanılmıştır. İstanbul Sabiha Gökçen Havalimanı için, işletmeci firma İSG'nin hisselerinin tamamını elinde bulunduran Malaysia Airports Holdings Berhad faaliyet raporlarından alınan veriler kullanılmıştır. Diğer YID ihaleleri için ise faaliyet raporlarındaki havalimanının bilgileri kullanılarak hesaplamalar yapılmıştır. Örnek olarak, Atatürk Havalimanının kalan işletme dönemi için yapılan hesaplamada TAV firmasının faaliyet raporlarına göre tespit edilen 2015-2016-2017 yıllarının 3 yıllık ortalamaları kullanılmıştır.

İhale süresi devam eden havalimanlarında tahmin edilen yolcu sayısı artışı Airbus ve Boeing firmaları ise 2018-2036 yılları arasında büyüme tahminleri ile DHMİ tarafından 20182020 yılları arasındaki tahminler ortalaması baz alınarak hesaplanmıştır.

Tablo 1. Havacılık Sektörü Büyüme Tahminleri

\begin{tabular}{|c|c|c|c|}
\hline & \multicolumn{3}{|c|}{ BÜYÜME TAHMINLERİ } \\
\hline & 2018 & 2019 & 2020 \\
\hline DHMİ & $13,00 \%$ & $7,00 \%$ & $6 \%$ \\
\hline Airbus & $4,40 \%$ & $4,40 \%$ & $4,40 \%$ \\
\hline Boeing & $4,20 \%$ & $4,20 \%$ & $4,20 \%$ \\
\hline Ortalama & $7,20 \%$ & $5,20 \%$ & $4,87 \%$ \\
\hline 3 Yilın Ortalamas 1 & \multicolumn{3}{|c|}{$5,76 \%$} \\
\hline
\end{tabular}

Tablo 1'de dünyanın en büyük uçak üretici firmaları arasında yer alan Airbus ve Boeing firmalarının gelecek yıllara ilişkin yolcu trafiği artış tahminleri ile DHMİ tarafından Türkiye için yapılan yolcu trafiğinin artış oranlarının toplamı alınarak her yılın aritmetik ortalaması bulunmuştur. 2018 yılı ve sonrasındaki yolcu trafiğindeki artış oranın belirlenmesi için 2018-2019 ve 2020 yılları için bulunan ortalamalar toplanarak yeniden aritmetik ortalama 
hesaplanmış ve $\% 5,76$ olarak bulunan oran 2018 ve sonrasındaki yolcu trafiği artışlarında kullanılmıştır.

Tablo 2. Faiz Oranları

\begin{tabular}{|c|c|c|}
\hline YIL & FAIZ ORANI & ORTALAMA \\
\hline 2013 & $4,19 \%$ & $4,19 \%$ \\
\hline 2014 & $3,75 \%$ & $3,97 \%$ \\
\hline 2015 & $3,51 \%$ & $3,82 \%$ \\
\hline 2016 & $3,75 \%$ & $3,80 \%$ \\
\hline 2017 & $3,51 \%$ & $3,74 \%$ \\
\hline 2018 (Ăgustos Sonu) & $3,79 \%$ & $3,75 \%$ \\
\hline
\end{tabular}

Kaynak: (https://stats.oecd.org, 2018)

İhale süresi devam eden havalimanlarının önümüzdeki dönemde kazanacakları yolcu servis gelirlerinin bugünkü değerinin bulunması amacıyla indirgenme oranı olarak Tablo 2'de yer alan ticari kredilerin ortalama faizi $(\% 3,75)$ ile Türkiye risk prim oranlarının ortalaması kullanılmıştır. Türkiye risk primindeki değişiklikler göz önünde bulundurularak son 6 yılın sonunda oluşan risk primi oranlarının aritmetik ortalaması hesaplanmış $(\% 2,79)$ ve faiz oranının $(\% 3,75)$ dâhil edilmesi ile $\% 6,54$ iskonto oranı olarak kabul edilmiştir.

Tablo 3. Risk Primi Oranı

\begin{tabular}{|c|c|c|}
\hline YIL & RISK PRIMI & FAİZ ORANI ORTALAMA \\
\hline 2013 & $2,34 \%$ & \\
\hline 2014 & $1,84 \%$ & \\
\hline 2015 & $2,75 \%$ & \\
\hline 2016 & $2,72 \%$ & \\
\hline 2017 & $1,59 \%$ & \\
\hline 2018 (Ăgustos Sonu) & $5,50 \%$ & \\
\hline Ortalama & $2,79 \%$ & $3,75 \%$ \\
\hline İskonto Oranı & $6,54 \%$ & \\
\hline
\end{tabular}

Kaynak: (www.bloomberght.com, 2018)

Para birimi olarak her ihalede kamu tarafindan tespit edilen para birimlerine göre hesaplama yapılmış olup tablolarda ortak bir para birimi kullanılmasını teminen tüm hesaplamalar Avro para cinsine çevrilmiş, kur çevriminde Tablo 4'deki değerler kullanılmıştır. 
Tablo 4. Yı1lar İtibariyle Döviz Kurları

\begin{tabular}{|c|c|c|c|}
\hline YIL & USD & AVRO & PARITE \\
\hline 1998 & 0,2600 & & 1,0000 \\
\hline 1999 & 0,4200 & 0,4450 & 1,0595 \\
\hline 2000 & 0,6230 & 0,5730 & 0,9197 \\
\hline 2001 & 1,2250 & 1,0930 & 0,8922 \\
\hline 2002 & 1,5050 & 1,4290 & 0,9495 \\
\hline 2003 & 1,4930 & 1,6850 & 1,1286 \\
\hline 2004 & 1,4220 & 1,7670 & 1,2426 \\
\hline 2005 & 1,3410 & 1,6700 & 1,2453 \\
\hline 2006 & 1,4310 & 1,8000 & 1,2579 \\
\hline 2007 & 1,3020 & 1,7780 & 1,3656 \\
\hline 2008 & 1,2930 & 1,8960 & 1,4664 \\
\hline 2009 & 1,5470 & 2,2150 & 1,4318 \\
\hline 2010 & 1,5000 & 1,9890 & 1,3260 \\
\hline 2011 & 1,6700 & 2,3220 & 1,3904 \\
\hline 2012 & 1,7930 & 2,3040 & 1,2850 \\
\hline 2013 & 1,9010 & 2,5250 & 1,3282 \\
\hline 2014 & 2,1880 & 2,9060 & 1,3282 \\
\hline 2015 & 2,7200 & 3,0180 & 1,1096 \\
\hline 2016 & 3,0210 & 3,3400 & 1,1056 \\
\hline 2017 & 3,6480 & 4,1160 & 1,1283 \\
\hline
\end{tabular}

Kaynak: TCMB

\section{BULGULAR}

\section{1. $\quad$ Atatürk Havalimanı Yap İşlet Devret İhalesi Mali İncelemesi}

1998 yılında TAV ve DHMİ arasında Atatürk Uluslararası Havalimanı uluslararası terminal binasının yeniden inşası yatırım ve işletilmesini düzenleyen YID sözleşmesi yapılmıştır. Haziran 2000'de terminal binasının \%30 genişlemesi taahhüdü ile Haziran 2005'e kadar süre uzatılmış, toplam işletme süresi 66 ay olarak belirlenmiştir. (TAV, 2018: 102) Sözleşme gereği olarak yapılan on dört milyon yolcu kapasiteli yeni dış hatlar terminali daha sonra terminal kapasitesinin yirmi milyon yolcuya çıkarılması ve ilave yatırımlarla beraber 397.793.500 USD'ye tamamlanmıştır. Dış hatlar terminali işletmeci firma olan TAV Yatırım, Yapım ve İşletme A.Ş. tarafından işletildikten sonra üzere 02.07.2005 tarihinde DHMİ'ye devredilmiştir.

Yukarıda sözleşme koşullarında görüldüğü üzere TAV Yatırım, Yapım ve İşletme A.Ş.'ye yolcu servis gelirleri dışında terminal işletmeciliğinin en büyük gelir kalemi olan kira, hasılat payı, yer tahsis ve reklam gelirleri ile yapılacak olan yedi bin araçlık katlı otoparkın gelirleri de tahsis edilmiştir. Atatürk Havalimanını görevli şirket TAV Yatırım, Yapım ve İşletme A.Ş 2000 ile 2005 yılları arasında işletmiş ve işletmiş olduğu süre zarfinda oluşan dış hat giden yolcu rakamları Tablo 5'de verilmiştir. 
Tablo 5. Atatürk Havalimanı YİD İhalesi Döneminde Gerçekleşen Yolcu Sayıları

\begin{tabular}{|c|c|}
\hline YIL & GERÇEKLEŞEN DIŞ HAT GIDEN YOLCU SAYISI \\
\hline 2000 & 4.851 .847 \\
\hline 2001 & 4.346 .810 \\
\hline 2002 & 4.091 .190 \\
\hline 2003 & 4.384 .388 \\
\hline 2004 & 5.154 .165 \\
\hline 2005 & 3.166 .140 \\
\hline & \\
\hline TOPLAM & $\mathbf{2 5 . 9 9 4 . 5 4 0}$ \\
\hline
\end{tabular}

Kaynak: DHMİ Yıllık İstatistikleri

Atatürk Havalimanı dış hatlar terminali, görevli şirket TAV Yatırım, Yapım ve İşletme A.Ş. tarafından DHMİ ile yaptığı sözleşmeye göre 2000 ile 2005 yılları arasında işletmiştir. İlgili yıllar arasındaki kâr zarar sonuçları Tablo 6'daki dış hat giden yolcu sayısındaki gerçekleşmeler kullanılarak hesaplanmış sonuçlar aşağıda özetlenmiştir. 2005 yılı dış hat giden yolcu haziran ayı sonu itibariyle verilmiştir.

Tablo 6. Atatürk Havalimanı YID İhalesi Yolcu Garantisi

\begin{tabular}{|c|c|c|}
\hline YIL & YOLCU GARANTISİ & BİR ÖNCEKİ YILA GÖRE ARTIŞ \\
\hline 2000 & 4.000 .000 & \\
\hline 2001 & 4.120 .000 & $3 \%$ \\
\hline 2002 & 4.243 .600 & $3 \%$ \\
\hline 2003 & 4.370 .908 & $3 \%$ \\
\hline 2004 & 4.502 .035 & $3 \%$ \\
\hline 2005 & 4.637 .096 & $3 \%$ \\
\hline
\end{tabular}

Kaynak: Avşar, 2012: 114

Atatürk Havalimanı dış hatlar ihale sözleşmesine göre dış hat yolcu servis ücretleri 15 USD olarak tespit edilmiştir. Tablo 6'da sözleşme kapsamında verilen dış hat yolcu garantileri yer almaktadır. Tablo 5 ve Tablo 6'daki dış hat yolcu garantileri ve gerçekleşmeler incelendiğinde; 2000, 2001, 2003, 2004 ve 2005 (alt1 ayda olarak 3.166.140 yolcu sayısına ulaşılmıştır) yıllarında garanti yolcu sayısının üzerinde gerçekleşmeler olduğu görülmektedir. 2002 yılında ise 4.243.600 dış hat garanti yolcu sayısına göre gerçekleşme 4.091.190 yolcu olmuştur. Buna göre hesaplanan yolcu servis gelirleri Tablo 7'de gösterilmiştir. 
Tablo 7. Atatürk Havalimanı YİD İhalesi Yolcu Servis Gelirleri (Milyon USD/Avro)

\begin{tabular}{|l|c|c|c|c|c|c|c|}
\hline GELİRLER (USD) & $\mathbf{2 0 0 0}$ Yılı & $\mathbf{2 0 0 1}$ Yılı & $\mathbf{2 0 0 2}$ Yılı & $\mathbf{2 0 0 3}$ Yılı & $\mathbf{2 0 0 4}$ Yılı & $\mathbf{2 0 0 5}$ Yılı & TOPLAM \\
\hline Yolcu Servis Gelirleri & 72,78 & 65,20 & 61,37 & 65,77 & 77,31 & 47,49 & $\mathbf{3 8 9 , 9 2}$ \\
\hline Yolcu Garantisi Geliri & 0,00 & 0,00 & 2,29 & 0,00 & 0,00 & 0,00 & $\mathbf{2 , 2 9}$ \\
\hline TOPLAM GELİR (USD) & 72,78 & 65,20 & 63,65 & 65,77 & 77,31 & 47,49 & $\mathbf{3 9 2 , 2 0}$ \\
\hline PARİTE USD/AVRO & 0,9197 & 0,8922 & 0,9495 & 1,1286 & 1,2426 & 1,2453 & \\
\hline $\begin{array}{l}\text { TOPLAM GELİR } \\
\text { (AVRO) }\end{array}$ & 79,13 & 73,08 & 67,04 & 58,27 & 62,22 & 38,14 & $\mathbf{3 7 7 , 8 8}$ \\
\hline
\end{tabular}

Tablo 7'de yer alan ve Atatürk Havalimanı YID ihalesinin sonuçlarını analize göre 66 aylık süreyi kapsayan işletme süresi boyunca 377,88 milyon Avro tutarında yolcu servis gelirleri oluşmuştur. TAV şirketinin 2005 ile 2017 yılları arasındaki faaliyet raporlarına göre yolcu servis gelirleri toplam cironun \%36'sina denk gelmektedir. Toplam FAVÖK ise cironun \%42'si oranındadır. Bu oranlar Atatürk Havalimanının YID ihalesi yolcu servis gelirlerine uygulandığında toplam ciro $(377.88 / 0,36) 1.049,44$ milyon Avro olarak FAVÖK tutarı ise $(1.049,44 * 0,42) 440,76$ milyon Avro olarak hesaplanmaktadır.

\subsection{Sabiha Gökçen Havalimanı Yap İşlet Devret İhalesi Mali İncelemesi}

Savunma Sanayii Başkanlığı tarafından 2007 yılında yapılan ihale sonucunda görevli şirket İstanbul Sabiha Gökçen Havalimanı Yapım Yatırım ve İşletim A.Ş. ile 01 Mayıs 2008 tarihinde sözleşme imzalanmıştır. Sözleşme kapsamında 253 milyon Avro tutarında yatırım yapılmıştır. Görevli şirket İSG sözleşme tarihi itibariyle terminal hizmetleri, akaryakıt, kargo, antrepo ve yer hizmetlerini havalimanında sürdürmeye başlamıştır. Sabiha Gökçen Havalimanı YID ihalesi, DHMİ'nin o tarihe göre yapmış olduğu diğer YİD ihalelerinden farklı olarak terminal hizmetlerinin yanında, akaryakıt, kargo, antrepo, yer hizmetleri de görevli şirkete vermiştir. 2007 yılında yapılan ihalede ve 2008 yılında imzalanan sözleşmede Türkiye'nin önemli inşaat şirketlerinden Limak Holding, Hindistan'ın önde gelen altyap1 gruplarından GMR Infrastructure ve Malezya devletinin sahip olduğu Malaysia Airports Holdings Berhad ortaklığında kurulan üçlü konsorsiyum, Limak ve GMR'ın hisselerini Malaysia Airports Holdings Berhad'a satması sonrasında yoluna tek ortaklı olarak devam etmektedir. Savunma

Sanayii Başkanlığı ile yapılan sözleşme kapsamında kira ödemeleri yatırım dönemini kapsayan ilk üç yıl boyunca ödemesizdir.

Tablo 8'deki dönemler boyunca 1.932 milyon Avro işletmeci tarafindan Savunma Sanayii Başkanlığına (SSB) kira bedeli ödenecektir. Sözleşmenin başlangıcı olan 2008 Mayıs ayından 2017 yılsonuna kadar gerçekleşen yolcu sayıları Tablo 8'daki gibidir. İhale şartnamesinde dış hat giden yolcu için 12 Avro, iç hat giden yolcu için ise 3 Avro belirlenmiş olup ücret tarifesinde yapılacak değişiklik sonrasında artırılan tutarın görevli şirket ile SSB arasında yarı yarıya paylaşılacağı belirlenmiştir. Dış hat ücretleri ihale sonrasında 15 Avro'ya yükseltilmiş ayrıca dış hat transfer ücreti için de 5 Avro yeni bir ücret konulmuştur. 
Tablo 8. Sabiha Gökçen Havalimanı YİD İhalesi Gerçekleşen Yolcu Sayıları

\begin{tabular}{|c|c|c|c|}
\hline YIL & $\begin{array}{c}\text { GERÇEKLEŞEN DIŞ HAT } \\
\text { GIDEN YOLCU SAYISI }\end{array}$ & $\begin{array}{c}\text { GERÇEKLEŞEN DIŞ HAT } \\
\text { TRANSIT GIDEN YOLCU } \\
\text { SAYISI }\end{array}$ & $\begin{array}{c}\text { GERÇEKLEŞEN İÇ HAT } \\
\text { GIDEN YOLCU SAYISI }\end{array}$ \\
\hline 2008 & 567.453 & 38.061 & 979.706 \\
\hline 2009 & 1.008 .860 & 85.694 & 2.234 .944 \\
\hline 2010 & 1.806 .358 & 221.127 & 3.679 .383 \\
\hline 2011 & 2.193 .819 & 144.158 & 4.165 .835 \\
\hline 2012 & 2.416 .797 & 98.448 & 4.479 .984 \\
\hline 2013 & 2.694 .095 & 588.793 & 5.280 .576 \\
\hline 2014 & 3.276 .568 & 893.437 & 6.400 .232 \\
\hline 2015 & 3.674 .919 & 1.017 .735 & 7.870 .405 \\
\hline 2016 & 3.627 .239 & 1.151 .244 & 8.745 .111 \\
\hline 2017 & 3.881 .084 & 1.256 .592 & 9.221 .688 \\
\hline TOPLAM & $\mathbf{2 5 . 1 4 7 . 1 9 2}$ & $\mathbf{5 . 4 9 5 . 2 8 9}$ & $\mathbf{5 3 . 0 5 7 . 8 6 4}$ \\
\hline
\end{tabular}

Kaynak: HEAŞ Faaliyet Raporları

Tablo 8'e göre ihalenin gerçekleşen döneminde 25 milyon diş hat doğrudan giden yolcu, 5,5 milyon transit giden yolcu ve 53 milyon iç hat giden yolcu havalimanını kullanmıştır. Bu verilere göre oluşan yolcu servis gelirleri Tablo 9'daki gibi oluşmuştur.

Tablo 9. Sabiha Gökçen Havalimanı YID İhalesi Yolcu Servis Gelirleri (Gerçekleşen Dönem) (Milyon Avro)

\begin{tabular}{|l|c|c|c|c|c|c|}
\hline GELİRLER & $\mathbf{2 0 0 8}$ Yılı & $\mathbf{2 0 0 9}$ Yılı & $\mathbf{2 0 1 0}$ Yılı & $\mathbf{2 0 1 1}$ Yılı & $\mathbf{2 0 1 2}$ Yılı & $\mathbf{2 0 1 3}$ Yılı \\
\hline Yolcu Servis Gelirleri & 10,69 & 20,54 & 35,98 & 42,47 & 46,31 & 53,68 \\
\hline Yolcu Garantisi Geliri & 0,00 & 0,00 & 0,00 & 0,00 & 0,00 & 0,00 \\
\hline TOPLAM GELİR & $\mathbf{1 0 , 6 9}$ & $\mathbf{2 0 , 5 4}$ & $\mathbf{3 5 , 9 8}$ & $\mathbf{4 2 , 4 7}$ & $\mathbf{4 6 , 3 1}$ & $\mathbf{5 3 , 6 8}$ \\
\hline GELİRLER & $\mathbf{2 0 1 4}$ Yılı & $\mathbf{2 0 1 5}$ Yılı & $\mathbf{2 0 1 6}$ Yılı & $\mathbf{2 0 1 7}$ Yılı & TOPLAM & $\mathbf{5 1 2 , 4 0}$ \\
\hline Yolcu Servis Gelirleri & 65,67 & 75,77 & 78,08 & 83,20 & $\mathbf{0 , 0 0}$ \\
\hline Yolcu Garantisi Geliri & & & & & $\mathbf{5 1 2 , 4 0}$ \\
\hline TOPLAM GELİR & $\mathbf{6 5 , 6 7}$ & $\mathbf{7 5 , 7 7}$ & $\mathbf{7 8 , 0 8}$ & $\mathbf{8 3 , 2 0}$ & &
\end{tabular}

Sabiha Gökçen Havalimanı ihalesinde yolcu garantisi verilmemiştir. Tablo 9'a göre işletme dönemi başlangıcı ile 2017 yılı arasında 512,40 milyon Avro yolcu servis geliri elde edilmiştir. Sabiha Gökçen Havalimanının işletmeci firması olan Malaysia Airports Holding Berhad'ın ulaşılabilen 2014, 2015 ve 2016 yılı faaliyet raporlarında sırasıyla aşağıdaki Tablo 10'de görüleceği üzere ciro ve FAVÖK (EBİTDA) rakamları verilmiştir. 
Tablo 10. Sabiha Gökçen Havalimanı YİD İhalesi Ciro ve EBİTDA Bilgileri

\begin{tabular}{|l|c|c|c|}
\hline \multicolumn{1}{|c|}{ Yıl } & 2014 Yılı & 2015 Yllı & 2016 Yllı \\
\hline Ciro Toplamı (Milyon MYR) & 805,70 & 908,00 & 958,00 \\
\hline EBİTDA (Milyon MYR) & 642,00 & 813,90 & 795,00 \\
\hline Avro/MYR Paritesi & 4,16 & 4,50 & 4,60 \\
\hline Ciro (Milyon Avro) & 193,68 & 201,78 & 208,26 \\
\hline EBİTDA (Milyon Avro) & 154,33 & 180,87 & 172,83 \\
\hline
\end{tabular}

Kaynak: Malaysia Airports Holding Berhad Faaliyet Raporları

Tablo 10'deki verilere göre FAVÖK olarak verilen rakamların içerisinde kira giderleri yer almamaktadır. İhale kira bedeli 1.932 milyon Avro'dur. 20 yılı kapsayan işletme süresince yıllara eşit olarak dağıtılan kira gideri yıllık 96,6 milyon Avro (1.932.000.000/20 Y11) olarak hesaplanmakta bu tutarda ciro ile FAVÖK olarak faaliyet raporlarında verilen tutarın oldukça üzerindedir. Örnek olarak 2016 yılının ciro tutarı 208,26 milyon Avro iken FAVÖK 172,83 milyon Avro'dur. Arasındaki fark kira bedeli olan 96,6 milyon Avro'nun altında sadece genel giderleri kapsayan bir tutar olduğu sonucu çıkarılabilecektir. Malaysia Airports Holding Berhad faaliyet raporlarında ciro ve FAVÖK verileri Malezya para birimi olarak verilmiş, ilgili yılların Avro/MYR paritesi ile Avro'ya çevrilmiştir. Yeniden düzenlenen ve FAVÖK rakamlarına getirilen Tablo 11'de yer almaktadır.

Tablo 11. Sabiha Gökçen Havalimanı YİD İhalesi Ciro ve FAVÖK Bilgileri

\begin{tabular}{|l|c|c|c|}
\hline \multicolumn{1}{|c|}{ YIL } & $\mathbf{2 0 1 4}$ Yılı & $\mathbf{2 0 1 5}$ Yılı & $\mathbf{2 0 1 6}$ Yılı \\
\hline Ciro Toplamı (Milyon MYR) & 805,70 & 908,00 & 958,00 \\
\hline EBİTDA (Milyon MYR) & 642,00 & 813,90 & 795,00 \\
\hline Avro/MYR Paritesi & 4,16 & 4,50 & 4,60 \\
\hline Ciro (Milyon Avro) & 193,68 & 201,78 & 208,26 \\
\hline Yolcu Servis Gelirleri (Avro) & 65,67 & 75,77 & 78,08 \\
\hline Diğer Gelirler (Avro) & 128,01 & 126,01 & 130,18 \\
\hline EBİTDA (Milyon Avro) & 154,33 & 180,87 & 172,83 \\
\hline Kira Gideri & 96,60 & 96,60 & 96,60 \\
\hline FAVÖK (Milyon Avro) & 57,73 & 84,27 & 76,23 \\
\hline $\begin{array}{l}\text { Diğer Gelirlerin/Yolcu Servis Gelirlerine } \\
\text { Oranı (3 yıl ortalaması) }\end{array}$ & 1,75 & & \\
\hline \multicolumn{2}{|l|}{} & 0,36 & \\
\hline
\end{tabular}

Malaysia Airports Holding Berhad'ın ulaşılabilen faaliyet raporlarına göre son 3 yılda diğer gelirler yolcu servis gelirlerinin \%175 fazlası olarak hesaplanmıştır. Bu oranı Sabiha Gökçen Havalimanın 2008 ile 2017 y1lı yolcu servis verirlerine uygulandığında gerçekleşen yolcu servis geliri 512,40 milyon Avro, \%175 fazlas1 896,70 milyon Avro (512,40*1,75) diğer gelirler olarak hesaplanmıştır. Toplam ciro 1.409,10 milyon Avro $(512,40+896,70)$ olarak oluşmuştur. Tablo 11'deki \%36 olan FAVÖK/ciro oranına göre Sabiha Gökçen Havalimanın gerçekleşen dönemdeki FAVÖK tutarı 507,27 milyon Avro $(1.409,10 * 0,36)$ olarak hesaplanmıştır. 
2018 yılı ile 2028 yılı arasındaki Tablo 1'deki veriler 1şı̆̆ında hesaplanan tahmini yolcu sayıları Tablo 12'deki gibidir.

Tablo 12. Sabiha Gökçen Havalimanı YİD İhalesi Kalan İşletme Dönemi İçin Tahmin Edilen Yolcu Sayıları

\begin{tabular}{|c|c|c|c|}
\hline ARTIŞ ORANI & $\mathbf{5 , 7 6 \%}$ & \multicolumn{2}{|c|}{} \\
\hline YIL & $\begin{array}{c}\text { GERÇEKLEŞEN DIŞ HAT } \\
\text { GIDEN YOLCU SAYISI }\end{array}$ & $\begin{array}{c}\text { GERÇEKLEŞEN DIŞ HAT } \\
\text { TRANSIT GIDEN YOLCU } \\
\text { SAYISI }\end{array}$ & $\begin{array}{c}\text { GERÇEKLEŞEN IÇ HAT } \\
\text { GIDEN YOLCU SAYISI }\end{array}$ \\
\hline 2018 & 4.104 .634 & 1.328 .972 & 9.752 .857 \\
\hline 2019 & 4.341 .061 & 1.405 .520 & 10.314 .622 \\
\hline 2020 & 4.591 .107 & 1.486 .478 & 10.908 .744 \\
\hline 2021 & 4.855 .554 & 1.572 .100 & 11.537 .088 \\
\hline 2022 & 5.135 .234 & 1.662 .653 & 12.201 .624 \\
\hline 2023 & 5.431 .024 & 1.758 .421 & 12.904 .437 \\
\hline 2024 & 5.743 .851 & 1.859 .706 & 13.647 .733 \\
\hline 2025 & 6.074 .696 & 1.966 .825 & 14.433 .842 \\
\hline 2026 & 6.424 .599 & 2.080 .115 & 15.265 .232 \\
\hline 2027 & 6.794 .656 & 2.199 .929 & 16.144 .509 \\
\hline 2028 & 2.395 .343 & 775.548 & 5.691 .478 \\
\hline & & & $\mathbf{1 3 2 . 8 0 2 . 1 6 6}$ \\
\hline TOPLAM & $\mathbf{5 5 . 8 9 1 . 7 5 9}$ & $\mathbf{1 8 . 0 9 6 . 2 6 8}$ & \\
\hline
\end{tabular}

Tablo 12'deki tahmini yolcu verilerine göre kalan işletme döneminde 56 milyon diş hat doğrudan giden yolcu, 18 milyon dış hat transfer/transit yolcu ve 133 milyon iç hat giden yolcu olacağı hesaplanmıştır. Bu yolcu sayılarına göre yolcu servis gelirleri Tablo 13 'te yer aldığ 1 şekilde oluşacağı öngörülmektedir. Sözleşme süresi 2028 Nisan sonunda biteceğinden 2028 y1lı yolcu verileri dört aylık olarak alınmıştır.

Tablo 13. Sabiha Gökçen Havalimanı YİD İhalesi Yolcu Servis Gelirleri (Kalan İşletme Dönemi) (Milyon Avro)

\begin{tabular}{|l|c|c|c|c|c|c|}
\hline GELİRLER & $\mathbf{2 0 1 8}$ Yılı & $\mathbf{2 0 1 9}$ Yılı & $\mathbf{2 0 2 0}$ Yılı & $\mathbf{2 0 2 1}$ Yılı & $\mathbf{2 0 2 2}$ Yılı & $\mathbf{2 0 2 3}$ Yılı \\
\hline Yolcu Servis Gelirleri & 87,99 & 93,06 & 98,42 & 104,09 & 110,09 & 116,43 \\
\hline Yolcu Garantisi Geliri & 0,00 & 0,00 & 0,00 & 0,00 & 0,00 & $\mathbf{0 , 0 0}$ \\
\hline TOPLAM GELİR & $\mathbf{8 7 , 9 9}$ & $\mathbf{9 3 , 0 6}$ & $\mathbf{9 8 , 4 2}$ & $\mathbf{1 0 4 , 0 9}$ & $\mathbf{1 1 0 , 0 9}$ & $\mathbf{1 1 6 , 4 3}$ \\
\hline & & & & & & \\
\hline Faiz Oranı & $3,75 \%$ & $3,75 \%$ & $3,75 \%$ & $3,75 \%$ & $3,75 \%$ & $3,75 \%$ \\
\hline Risk Primi & $2,79 \%$ & $2,79 \%$ & $2,79 \%$ & $2,79 \%$ & $2,79 \%$ & $2,79 \%$ \\
\hline İNDíRGENMiş GELír & $\mathbf{8 2 , 5 9}$ & $\mathbf{8 2 , 3 0}$ & $\mathbf{8 2 , 2 8}$ & $\mathbf{8 2 , 5 1}$ & $\mathbf{8 2 , 9 6}$ & $\mathbf{8 3 , 6 2}$ \\
\hline & & & & & & \\
\hline GELİRLER & $\mathbf{2 0 2 4}$ Yılı & $\mathbf{2 0 2 5}$ Yılı & $\mathbf{2 0 2 6}$ Ylı & $\mathbf{2 0 2 7}$ Yılı & $\mathbf{2 0 2 8}$ Yılı & TOPLAM \\
\hline
\end{tabular}




\begin{tabular}{|l|c|c|c|c|c|c|} 
Yolcu Servis Gelirleri & 123,13 & 130,23 & 137,73 & 145,66 & 51,35 & $\mathbf{1 . 1 9 8 , 1 9}$ \\
\hline Yolcu Garantisi Geliri & 0,00 & 0,00 & 0,00 & 0,00 & 0,00 & $\mathbf{0 , 0 0}$ \\
\hline TOPLAM GELİR & $\mathbf{1 2 3 , 1 3}$ & $\mathbf{1 3 0 , 2 3}$ & $\mathbf{1 3 7 , 7 3}$ & $\mathbf{1 4 5 , 6 6}$ & $\mathbf{5 1 , 3 5}$ & $\mathbf{1 . 1 9 8 , 1 9}$ \\
\hline & & & & & & \\
\hline Faiz Oranı & $3,75 \%$ & $3,75 \%$ & $3,75 \%$ & $3,75 \%$ & $3,75 \%$ & $3,75 \%$ \\
\hline Risk Primi & $2,79 \%$ & $2,79 \%$ & $2,79 \%$ & $2,79 \%$ & $2,79 \%$ & $2,79 \%$ \\
\hline İNDİRGENMISS GELİR & $\mathbf{8 4 , 4 7}$ & $\mathbf{8 5 , 5 0}$ & $\mathbf{8 6 , 7 0}$ & $\mathbf{8 8 , 0 7}$ & $\mathbf{2 9 , 8 7}$ & $\mathbf{8 7 0 , 8 4}$ \\
\hline
\end{tabular}

Tablo 13'de Sabiha Gökçen YID ihalesinin kalan dönemin yolcu servis gelirleri diğer hesaplamalarda olduğu gibi 2017 yılı sayıları üzerine Tablo 1'deki büyüme tahminleri eklenerek yolcu sayısı tahminlerine hesaplanmıştır. 2018-2028 yıllarını kapsayan dönemde 2017 y1lına indirgenmiş 870,84 milyon Avro yolcu servis geliri oluşacaktır. Tablo 11'deki diğer gelirlerin yolcu servis gelirlerine oranı kullanılarak hesaplanan diğer gelir 1.523,97 milyon Avro $(870,84 * 1,75)$ ciro ise $2.394,81$ milyon Avro $(870,84+1.523,97)$ olarak hesaplanmıştır. Yine tablo 11'deki FAVÖK/ciro oranı kullanılarak yapılan hesaplamada FAVÖK 862,13 milyon Avro $(2.394,81 * 0,36)$ olarak çıkmaktadır. Sabiha Gökçen Havalimanının gerçekleşen ve kalan döneme ilişkin toplam FAVÖK geliri 1.369,40 milyon Avro olarak ortaya çıkmaktadır.

\subsubsection{Antalya Havalimanı İkinci Dış Hatlar Terminali Yap İşlet Devret İhalesi Mali İncelemesi}

Antalya Havalimanının ikinci dış hatlar terminalinin işletme süresi dört yıl beş ay sürmüştür. Görevli şirket Çelebi Hava Servisi Anonim Şirketi ile 2004 yılında yapılan anlaşma sonrasında Nisan 2005'de başlayan işletme süresi Eylül 2009 yılında son bulmuştur. Sözleşme ile yolcu servis ücreti 15 USD olarak belirlenmiştir. Sözleşme kapsamında yapılan yatırım tutarı 85.386.000 USD’dir. (DHMİ 2017 Faaliyet Raporu, 2017: 157) Sözleşme süresi boyunca gerçekleşen giden yolcu sayıları Tablo 14'deki gibidir.

Tablo 14. Antalya Havalimanı İkinci Terminal YİD İhalesi Gerçekleşen Yolcu Sayıları

\begin{tabular}{|c|c|c|c|}
\hline YIL & $\begin{array}{c}\text { GERÇEKLEŞEN DIŞ HAT } \\
\text { GIDEN YOLCU SAYISI }\end{array}$ & $\begin{array}{c}\text { GARANTI YOLCU } \\
\text { SAYISI }\end{array}$ & FARK \\
\hline 2005 & 2.400 .348 & 1.474 .092 & 926.256 \\
\hline 2006 & 3.102 .619 & 2.277 .472 & 825.147 \\
\hline 2007 & 5.085 .453 & 2.345 .796 & 2.739 .657 \\
\hline 2008 & 4.124 .631 & 2.416 .170 & 1.708 .461 \\
\hline 2009 & 2.905 .705 & 2.488 .655 & 417.050 \\
\hline & & & \\
\hline TOPLAM & $\mathbf{1 7 . 6 1 8 . 7 5 4}$ & $\mathbf{1 1 . 0 0 2 . 1 8 5}$ & $\mathbf{6 . 6 1 6 . 5 6 9}$ \\
\hline
\end{tabular}

Kaynak: DHMI İstatistikleri 
Tablo 14'de işletme dönemi boyunca havalimanını 17,6 milyon dış hat yolcu kullanmıştır. Antalya Havalimanının birinci ihalesinde olduğu gibi garanti yolcu servis gelirinin üzerinde bir gerçekleşme olmuş ve işletmeci firma 6,6 milyon olan bu farka ait gelirin tamamını DHMİye ödemiştir. Gerçekleşen yolcu sayılarına göre sözleşme dönemi içinde oluşan tahmini yolcu servis gelirleri Tablo 15'de sunulmuştur.

Tablo 15. Antalya Havalimanı İkinci Terminal YİD İhalesi Yolcu Servis Gelirleri (Milyon USD/Avro)

\begin{tabular}{|l|c|c|c|c|c|c|}
\hline GELIIRLER (Yıllık) & $\mathbf{2 0 0 5}$ & $\mathbf{2 0 0 6}$ & $\mathbf{2 0 0 7}$ & $\mathbf{2 0 0 8}$ & $\mathbf{2 0 0 9}$ & TOPLAM \\
\hline Yolcu Servis Gelirleri & 36,01 & 46,54 & 76,28 & 61,87 & 43,59 & $\mathbf{2 6 4 , 2 8}$ \\
\hline Yolcu Garantisi Geliri & & & & & & $\mathbf{0 , 0 0}$ \\
\hline DHMİ Yolcu Servis Ödemesi & 13,89 & 12,38 & 41,09 & 25,63 & 6,26 & $\mathbf{9 9 , 2 5}$ \\
\hline & & & & & & \\
\hline NET YOLCU SERVİ GELIIRI (USD) & $\mathbf{2 2 , 1 1}$ & $\mathbf{3 4 , 1 6}$ & $\mathbf{3 5 , 1 9}$ & $\mathbf{3 6 , 2 4}$ & $\mathbf{3 7 , 3 3}$ & $\mathbf{1 6 5 , 0 3}$ \\
\hline PARİTE & 1,2453 & 1,2579 & 1,3656 & 1,4664 & 1,4318 & \\
\hline YOLCU SERVIS GELİRLERI (AVRO) & $\mathbf{2 8 , 9 1}$ & $\mathbf{3 7 , 0 0}$ & $\mathbf{5 5 , 8 6}$ & $\mathbf{4 2 , 1 9}$ & $\mathbf{3 0 , 4 4}$ & $\mathbf{1 9 4 , 4 0}$ \\
\hline DHMI YOLCU SERVIS (AVRO) & $\mathbf{1 1 , 1 6}$ & $\mathbf{9 , 8 4}$ & $\mathbf{3 0 , 0 9}$ & $\mathbf{1 7 , 4 8}$ & $\mathbf{4 , 3 7}$ & $\mathbf{7 2 , 9 3}$ \\
\hline NET YOLCU SERVIS GELIIRI (AVRO) & $\mathbf{1 7 , 7 6}$ & $\mathbf{2 7 , 1 6}$ & $\mathbf{2 5 , 7 7}$ & $\mathbf{2 4 , 7 2}$ & $\mathbf{2 6 , 0 7}$ & $\mathbf{1 2 1 , 4 7}$ \\
\hline
\end{tabular}

Antalya'nın birinci terminal ihalesinde garanti edilen yolcu sayısının üzerinde gerçekleşen yolcu sayısından sonra ikinci terminal ihalesinde garanti yolcuyu aşan sayının tamamının DHMI'ye ödeneceğine ilişkin maddeye sözleşmede yer verilerek birinci terminal ihalesinden daha başarılı bir şartname ortaya çıkarılmıştır. USD veriler Tablo 4'deki pariteler kullanılarak Avro'ya çevrilmiştir. Antalya Havalimanın KİD ihalesinin gerçekleşen dönemindeki verileri kullanarak toplam ciro 347,14 milyon Avro (194,40/0,56) olarak bulunmuştur. FAVÖK hesabında ise yine KID ihalesindeki FAVÖK/ciro oranından yola çıkarak 153,90 milyon Avro $(347,14 x 0,47)$ hesaplanmış ancak DHMİ ye ödenen ekstra yolu gelirlerinin düşülmesiyle FAVÖK 80,97 milyon Avro (153,90-72,93) bulunmuştur.

\subsection{2. İzmir Adnan Menderes Havalimanı Dış Hatlar Terminali Yap İşlet Devret İhalesi Mali İncelemesi}

İzmir Adnan Menderes Havalimanında yeni dış hatlar binası yapım ve işletim sözleşmesi 2005 yılında DHMİ Genel Müdürlüğü ile Havaş Havaalanları Yer Hizmetleri Anonim Şirketi arasında imzalanmıştır. Toplam işletme süresi yedi yıl dört ay yirmi altı gün sürmüştür. İzmir Adnan Menderes Havalimanında DHMİ tarafından garanti edilen yolcu sayısının altında bir gerçekleşme olmuştur. Sözleşme süresi içinde gerçekleşen yolcu sayıları Tablo 16'da özetlenmiştir. 
Tablo 16. İzmir Adnan Menderes Havalimanı Dış Hatlar Terminal YİD İhalesi

Gerçekleşen Yolcu Sayıları

\begin{tabular}{|c|c|c|}
\hline YIL & $\begin{array}{c}\text { GERÇEKLEŞEN DIS } \\
\text { HAT GIDEN YOLCU SAYISI }\end{array}$ & GARANTI \\
\hline 2006 & 732.142 & 1.000 .000 \\
\hline 2007 & 820.858 & 1.030 .000 \\
\hline 2008 & 859.940 & 1.060 .900 \\
\hline 2009 & 839.210 & 1.092 .727 \\
\hline 2010 & 1.063 .744 & 1.125 .509 \\
\hline 2011 & 1.199 .229 & 1.159 .274 \\
\hline 2012 & 1.205 .429 & 1.194 .052 \\
\hline 2013 & 1.239 .579 & 1.229 .874 \\
\hline 2014 & 1.290 .119 & 0 \\
\hline TOPLAM & $\mathbf{9 . 2 5 0 . 2 5 0}$ & $\mathbf{8 . 8 9 2 . 3 3 6}$ \\
\hline
\end{tabular}

Kaynak: DHMİ İstatistikleri

Tablo 16'da görüleceği üzere İzmir Adnan Menderes Havalimanının yapılan ilk terminal ihalesi önceki örneklerin aksine verilen yolcu garantilerinin altında kalmış ve kamu yolcu garantisi tazminatı ödemiştir. Özellikle 2006 ile 2009 yılları arasında garanti edilen yolcu sayısı gerçekleşen yolcu sayısının üzerinde gerçekleşmiştir. İşletme süresi boyuncu havalimanını 9,2 milyon dış hat giden yolcu kullanmıştır. Kamu tarafından verilen yolcu garantileri, yapılan terminal yatırımlarının ve işletme maliyetlerinin en azından karşılanması için hesaplanmış olup genel ticari kurallara uygundur. İzmir Adnan Menderes Havalimanında da 138 milyon Avro tutarında yatırım gerçekleştirilmiştir.

Tablo 17. İzmir Adnan Menderes Havalimanı Dış Hatlar Terminal YİD İhalesi Yolcu Servis Gelirleri (Milyon Avro)

\begin{tabular}{|l|c|c|c|c|c|c|c|c|c|c|}
\hline GELİRLER & $\mathbf{2 0 0 6}$ & $\mathbf{2 0 0 7}$ & $\mathbf{2 0 0 8}$ & $\mathbf{2 0 0 9}$ & $\mathbf{2 0 1 0}$ & $\mathbf{2 0 1 1}$ & $\mathbf{2 0 1 2}$ & $\mathbf{2 0 1 3}$ & $\mathbf{2 0 1 4}$ & TOPLAM \\
\hline Yolcu Servis Gelirleri & 10,98 & 12,31 & 12,90 & 12,59 & 15,96 & 17,99 & 18,08 & 18,59 & 19,35 & $\mathbf{1 3 8 , 7 5}$ \\
\hline Yolcu Garantisi Geliri & 4,02 & 3,14 & 3,01 & 3,80 & 0,93 & 0,00 & 0,00 & 0,00 & 0,00 & $\mathbf{1 4 , 9 0}$ \\
\hline TOPLAM GELİ & $\mathbf{1 5 , 0 0}$ & $\mathbf{1 5 , 4 5}$ & $\mathbf{1 5 , 9 1}$ & $\mathbf{1 6 , 3 9}$ & $\mathbf{1 6 , 8 8}$ & $\mathbf{1 7 , 9 9}$ & $\mathbf{1 8 , 0 8}$ & $\mathbf{1 8 , 5 9}$ & $\mathbf{1 9 , 3 5}$ & $\mathbf{1 5 3 , 6 5}$ \\
\hline
\end{tabular}

Tablo 17'de gerçekleşen yolcu sayılarına göre 153,65 milyon Avro olarak hesaplanan yolcu servis gelirleri yer almaktadır. Havaş Havaalanları Yer Hizmetleri Anonim Şirketi TAV Havalimanları Holding A.Ş.'nin iştirakleri arasında yer aldığından TAV firmasının 2007 ile 2017 yılları arasındaki faaliyet raporlarından alınan verilere göre ciro ve FAVÖK tutarları Tablo 18'de verilmiştir. 2006 yılı için ise 2007 yılı verileri kullanılarak hesaplama yapılmıştır. 
Tablo 18. İzmir Havalimanı YİD İhalesi Ciro ve FAVÖK Bilgileri

\begin{tabular}{|c|c|c|c|c|c|c|}
\hline YIL & CíRO & $\begin{array}{c}\text { YOLCU } \\
\text { SERVIS } \\
\text { CIROSU }\end{array}$ & $\begin{array}{c}\text { DíĞER } \\
\text { GELIRLER }\end{array}$ & FAVÖK & $\begin{array}{c}\text { YOLCU SERVIS } \\
\text { /CIRO ORANI }\end{array}$ & $\begin{array}{c}\text { FAVÖK/CiRO } \\
\text { ORANI }\end{array}$ \\
\hline 2006 & 28,16 & 15,00 & 13,16 & 13,79 & $53 \%$ & $49 \%$ \\
\hline 2007 & 29,00 & 15,45 & 13,55 & 14,20 & $53 \%$ & $49 \%$ \\
\hline 2008 & 29,60 & 15,91 & 13,69 & 16,00 & $54 \%$ & $54 \%$ \\
\hline 2009 & 28,70 & 16,39 & 12,31 & 16,50 & $57 \%$ & $57 \%$ \\
\hline 2010 & 32,70 & 16,88 & 15,82 & 19,40 & $52 \%$ & $59 \%$ \\
\hline 2011 & 35,00 & 17,99 & 17,01 & 22,00 & $51 \%$ & $63 \%$ \\
\hline 2012 & 57,00 & 18,08 & 38,92 & 25,08 & $32 \%$ & $44 \%$ \\
\hline 2013 & 60,00 & 18,59 & 41,41 & 27,30 & $31 \%$ & $46 \%$ \\
\hline 2014 & 65,40 & 19,35 & 46,05 & 39,20 & $30 \%$ & $60 \%$ \\
\hline TOPLAM & $\mathbf{3 6 5 , 5 6}$ & $\mathbf{1 5 3 , 6 5}$ & $\mathbf{2 1 1 , 9 0}$ & $\mathbf{1 9 3 , 4 7}$ & $\mathbf{4 2 \%}$ & $\mathbf{5 3 \%}$ \\
\hline
\end{tabular}

Kaynak: TAV Faaliyet Raporları

Tablo 18'de TAV Havalimanları Holding A.Ş.'nin faaliyet raporlarındaki verilerden alınan bilgilere göre ihale dönemi boyunca toplam 365,56 milyon Avro ciro 193,47 milyon Avro’da FAVÖK oluşmuştur.

\subsubsection{Ankara Esenboğa Havalimanı İç ve Dış Hatlar Terminali Yap İşlet Devret İhalesi Mali İncelemesi}

Esenboğa Havalimanı 2004 yılında imzalanan sözleşme ile Tepe İnşaat Sanayi Anonim Şirketine devredilmiştir. İhale kapsamında 188.702.557 Avro yatırım yapılmıştır. Toplam işletme süresi 15 yıl 8 aydır.

Tablo 19. Ankara Esenboğa Yolcu Terminalleri YİD İhalesi Gerçekleşen Yolcu Sayıları

\begin{tabular}{|c|c|c|c|c|}
\hline YIL & $\begin{array}{c}\text { GERÇEKLEŞEN DIŞ HAT } \\
\text { GIDEN YOLCU SAYISI }\end{array}$ & $\begin{array}{c}\text { GERÇEKLEŞEN IÇ } \\
\text { HAT GIDEN YOLCU } \\
\text { SAYISI }\end{array}$ & GARANTİ DIŞ & $\begin{array}{c}\text { GARANTİ } \\
\text { İÇ }\end{array}$ \\
\hline 2006 & 79.332 & 203.713 & 91.875 & 69.500 \\
\hline 2007 & 672.569 & 1.798 .271 & 750.000 & 600.000 \\
\hline 2008 & 621.657 & 2.209 .617 & 787.500 & 630.000 \\
\hline 2009 & 547.195 & 2.480 .608 & 826.875 & 661.500 \\
\hline 2010 & 664.347 & 3.217 .611 & 868.219 & 694.575 \\
\hline 2011 & 702.698 & 3.540 .036 & 911.630 & 729.304 \\
\hline 2012 & 796.869 & 3.839 .686 & 957.211 & 765.769 \\
\hline 2013 & 786.114 & 4.684 .916 & 1.005 .072 & 804.057 \\
\hline 2014 & 722.128 & 4.775 .289 & 1.055 .325 & 844.260 \\
\hline 2015 & 775.579 & 5.281 .141 & 1.108 .092 & 886.473 \\
\hline
\end{tabular}




\begin{tabular}{|c|c|c|c|c|}
\hline 2016 & 745.053 & 5.768 .082 & 1.163 .496 & 930.797 \\
\hline 2017 & 988.031 & 6.894 .735 & 1.221 .671 & 977.337 \\
\hline TOPLAM & $\mathbf{8 . 1 0 1 . 5 7 2}$ & $\mathbf{4 4 . 6 9 3 . 7 0 5}$ & $\mathbf{1 0 . 7 4 6 . 9 6 6}$ & $\mathbf{8 . 5 9 3 . 5 7 2}$ \\
\hline
\end{tabular}

Kaynak: DHMİ İstatistikleri

Tablo 19'da görüleceği üzere Ankara Esenboğa Havalimanında kamu tarafından yolcu garantisi verilmiştir. Gerçekleşen dönemde havalimanını 8,1 milyon dış hat giden yolcu, 45 milyon da iç hat giden yolcu kullanmıştır. İhale şartnamesine göre verilen garantilerde iç hat için verilen garanti yolcunun çok üzerinde gerçekleşmeler olur iken, dış hat yolcu sayısı 2006 ile 2017 yılları arasında yolcu sayısı garanti yolcu sayısının altında gerçekleşmiştir. Gerçekleşen yolcu sayılarına göre oluşan yolcu servis gelirleri Tablo 20'deki gibidir.

Tablo 20. Ankara Esenboğa Yolcu Terminalleri YIDD İhalesi Yolcu Servis Gelirleri Gerçekleşen Dönem (Milyon Avro)

\begin{tabular}{|c|c|c|c|c|c|c|c|}
\hline GELİRLER & 2006 Yilı & 2007 Yilı & 2008 Yilı & 2009 Yılı & 2010 Yilı & 2011 Yilı & \\
\hline Yolcu Servis Gelirleri & 1,80 & 15,48 & 15,95 & 15,65 & 19,62 & 21,16 & \\
\hline Yolcu Garantisi Geliri & 0,19 & 1,16 & 2,49 & 4,20 & 3,06 & 3,13 & \\
\hline TOPLAM GELİR & 1,99 & 16,64 & 18,44 & 19,84 & 22,68 & 24,29 & \\
\hline GELİRLER & 2012 Yılı & 2013 Yılı & 2014 Yılı & 2015 Yılı & 2016 Yılı & 2017 Yılı & TOPLAM \\
\hline Yolcu Servis Gelirleri & 23,47 & 25,85 & 25,16 & 27,48 & 28,48 & 35,50 & 255,60 \\
\hline Yolcu Garantisi Geliri & 2,41 & 3,28 & 5,00 & 4,99 & 6,28 & 3,50 & 39,68 \\
\hline TOPLAM GELİR & 25,88 & 29,13 & 30,16 & 32,46 & 34,76 & 39,01 & 295,29 \\
\hline
\end{tabular}

Tablo 20'de Ankara Esenboğa Havalimanın gerçekleşen dönemdeki yolcu sayılarına göre 295,29 milyon Avro yolcu servis geliri elde edilmiştir. İşletmeci firma Tepe İnşaat Sanayi Anonim Şirketi, TAV Havalimanları Holding iştirakidir. İstanbul Atatürk Havalimanı ve İzmir Adnan Menderes Havalimanlarında olduğu gibi TAV Havalimanları Holding A.Ş.'nin faaliyet raporlarından alınan bilgilere göre Ankara Esenboğa Havalimanının ciro ve FAVÖK bilgileri Tablo 21'deki gibi oluşmuştur. Faaliyet raporuna ulaşılamayan 2006 yılı için 2007 yılı verilerindeki oranlar kullanılmıştır. Ankara Esenboğa Havalimanında ihale şartnamesine göre verilen garanti yolcu sayısı gerçekleşen yolcu sayısının altında kalmıştır. Tablo 19'da gerçekleşen dış hat yolcu sayısı 8,1 milyon olurken, garanti yolcu sayısı 10,7 milyondur. Tablo 20'de görüleceği üzere 39,68 milyon Avro yolcu garantisi işletmeci firmaya ödendiği tahmin edilmektedir. 
Tablo 21. Ankara Esenboğa Havalimanı YİD İhalesi Ciro ve FAVÖK Bilgileri

\begin{tabular}{|c|c|c|c|c|c|c|}
\hline YIL & CİRO & $\begin{array}{c}\text { YOLCU } \\
\text { SERVIS } \\
\text { CiROSU }\end{array}$ & $\begin{array}{c}\text { Dí̆GER } \\
\text { GELIRLER }\end{array}$ & FAVÖK & $\begin{array}{c}\text { YOLCU SERVIS } \\
\text { /CiRO ORANI }\end{array}$ & $\begin{array}{c}\text { FAVÖK/CiRO } \\
\text { ORANI }\end{array}$ \\
\hline 2006 & 3,88 & 1,99 & 1,89 & 1,39 & $51 \%$ & $36 \%$ \\
\hline 2007 & 32,50 & 16,64 & 15,86 & 11,60 & $51 \%$ & $36 \%$ \\
\hline 2008 & 34,20 & 18,44 & 15,76 & 11,90 & $54 \%$ & $35 \%$ \\
\hline 2009 & 33,00 & 19,84 & 13,16 & 13,10 & $60 \%$ & $40 \%$ \\
\hline 2010 & 37,90 & 22,68 & 15,22 & 15,30 & $60 \%$ & $40 \%$ \\
\hline 2011 & 42,00 & 24,29 & 17,71 & 20,00 & $58 \%$ & $48 \%$ \\
\hline 2012 & 45,00 & 25,88 & 19,12 & 19,80 & $58 \%$ & $44 \%$ \\
\hline 2013 & 48,10 & 29,13 & 18,97 & 21,40 & $61 \%$ & $44 \%$ \\
\hline 2014 & 47,20 & 30,16 & 17,04 & 22,00 & $64 \%$ & $47 \%$ \\
\hline 2015 & 51,50 & 32,46 & 19,04 & 24,70 & $63 \%$ & $48 \%$ \\
\hline 2016 & 67,50 & 34,76 & 32,74 & 40,60 & $51 \%$ & $60 \%$ \\
\hline 2017 & 67,40 & 39,01 & 28,39 & 44,50 & $58 \%$ & $66 \%$ \\
\hline TOPLAM & $\mathbf{5 1 0 , 1 8}$ & $\mathbf{2 9 5 , 2 9}$ & $\mathbf{2 1 4 , 9 0}$ & $\mathbf{2 4 6 , 2 9}$ & $\mathbf{5 8 \%}$ & $\mathbf{4 8 \%}$ \\
\hline
\end{tabular}

Kaynak: TAV Faaliyet Raporları

Tablo 21'e göre gerçekleşen işletme döneminde 510,18 milyon Avro ciro ve 246,29 milyon Avro FAVÖK oluşmuştur. Gerçekleşen dönemde \%58 olarak oluşan yolcu servis gelirleri/ciro oranı ile \%48 olarak gerçekleşen FAVÖK/ciro oranları Ankara Esenboğa Havalimanının kalan işletme döneminde tahmini yolcu sayılarına göre oluşan yolcu servis gelirlerine uygulanacaktır.

Tablo 22. Ankara Esenboğa Yolcu Terminalleri YİD İhalesi Kalan İşletme Dönemi İçin Tahmin Edilen Yolcu Sayıları

\begin{tabular}{|c|c|c|c|}
\hline Artış Oranı & $\mathbf{5 , 7 6 \%}$ & \multicolumn{2}{|c|}{} \\
\hline YIL & $\begin{array}{c}\text { TAHMIN EDILEN DIŞ HAT } \\
\text { GIDEN YOLCU SAYISI }\end{array}$ & $\begin{array}{c}\text { TAHMIN EDILEN İÇ } \\
\text { HAT GíDEN YOLCU } \\
\text { SAYISI }\end{array}$ & GARANTI DIŞI \\
\hline 2018 & 1.044 .942 & 7.291 .872 & 1.282 .755 \\
\hline 2019 & 1.105 .130 & 7.711 .884 & 1.346 .892 \\
\hline 2020 & 1.168 .786 & 8.156 .088 & 1.414 .237 \\
\hline 2021 & 1.236 .108 & 8.625 .879 & 1.484 .949 \\
\hline 2022 & 1.307 .308 & 9.122 .729 & \\
\hline 2023 & 576.087 & 4.020 .083 & \\
\hline TOPLAM & $\mathbf{6 . 4 3 8 . 3 6 0}$ & $\mathbf{4 4 . 9 2 8 . 5 3 4}$ & $\mathbf{5 . 5 2 8 . 8 3 3}$ \\
\hline
\end{tabular}

Tablo 22'de 2018 ile ihale dönemi sonuna kadar olan ve Tablo 1'deki oranlarla artırılan yolcu sayıları yer almaktadır. Tabloda iç hat garanti yolcu sayısı mevcut gerçekleşen yolcu sayısının oldukça altında kalması sebebiyle garanti iç hat giden yolcu sayıları 
yazılmamıştır. Kalan işletme dönemi boyunca 6,4 milyon dış hat giden yolcu, 45 milyonda iç hat giden yolcunun havalimanını kullanacağı tahmin edilmektedir. Tahmini yolcu sayılarına göre gerçekleşmesi muhtemel yolcu servis gelirleri aşağıdaki Tablo 23'deki gibi hesaplanmıştır.

Tablo 23. Ankara Esenboğa Yolcu Terminalleri YID İhalesi Yolcu Servis Gelirleri (Kalan İşletme Dönemi) (Milyon Avro)

\begin{tabular}{|l|c|c|c|c|c|c|c|}
\hline GELİRLER & $\mathbf{2 0 1 8}$ Yıl & $\mathbf{2 0 1 9}$ Yll & $\mathbf{2 0 2 0}$ Yll & $\mathbf{2 0 2 1}$ Yıll & $\mathbf{2 0 2 2}$ Yılı & $\mathbf{2 0 2 3}$ Yılı & TOPLAM \\
\hline Yolcu Servis Gelirleri & 37,55 & 39,71 & 42,00 & 44,42 & 46,98 & 20,70 & $\mathbf{2 3 1 , 3 6}$ \\
\hline Yolcu Garantisi & 3,57 & 3,63 & 3,68 & 3,73 & 0,00 & 0,00 & $\mathbf{1 4 , 6 1}$ \\
\hline TOPLAM GELİR & $\mathbf{4 1 , 1 2}$ & $\mathbf{4 3 , 3 4}$ & $\mathbf{4 5 , 6 8}$ & $\mathbf{4 8 , 1 5}$ & $\mathbf{4 6 , 9 8}$ & $\mathbf{2 0 , 7 0}$ & $\mathbf{2 4 5 , 9 7}$ \\
\hline Faiz Oranı & $3,75 \%$ & $3,75 \%$ & $3,75 \%$ & $3,75 \%$ & $3,75 \%$ & $3,75 \%$ & \\
\hline Risk Primi & $2,79 \%$ & $2,79 \%$ & $2,79 \%$ & $2,79 \%$ & $2,79 \%$ & $2,79 \%$ & \\
\hline $\begin{array}{l}\text { İNDİRGENMíŞ } \\
\text { GELİR }\end{array}$ & $\mathbf{3 8 , 5 9}$ & $\mathbf{3 8 , 3 3}$ & $\mathbf{3 8 , 1 9}$ & $\mathbf{3 8 , 1 7}$ & $\mathbf{3 5 , 4 0}$ & $\mathbf{1 4 , 8 7}$ & $\mathbf{2 0 3 , 5 4}$ \\
\hline
\end{tabular}

Tablo 23'de görüldüğü üzere 2018 ile 2023 yılları arasında 203,54 milyon Avro yolcu servis geliri olacağı öngörülmüştür. Gerçekleşen dönemdeki oranları kullanılarak yapılan hesaplamada ciro tutarının 350,93 milyon Avro $(203,54 / 0,48)$ FAVÖK'ün ise 168,45 milyon Avro $(350,93 * 0,48)$ olacağı hesaplanmıştır. Gerçekleşen dönemle birlikte değerlendirildiğinde toplam FAVÖK'ün 414,74 milyon Avro olacağı hesaplanmıştır.

\section{SONUÇ}

İncelenen havalimanlarındaki analiz sonuçlarına göre havacılık sektörü için yapılacak olan YİD ihalelerinde, şartname aşamasında kurulacak görevli şirketlere terminal kapasitesi ve potansiyelleri dikkate alınarak kamu sermayeli şirketlerin ortak olması koşulunun getirilmesi ve kamunun daha fazla operasyonun içinde olması yerinde olacağı düşünülmektedir.

Yapılan tahmini çalışmalara göre üç büyük havalimanının YID ihalelerinin toplam işletmeci FAVÖK tutarının 2,5 milyar Avro olacağı tahmin edilmektedir. Diğer YIDD ihalelerini ve YID sonrasında yapılan Kirala İşlet Devret metodu ile yapılan işletmecilikleri de dahil ettiğimizde toplam FAVÖK karlılıkları daha üst seviyelere çıkacaktır. Yukarıda incelenenler özelinde, örneğin kurulan şirketlerde \%20'lik bir kamu hissesi olsaydı yaklaşık 500 milyon Avro tutarında devlet hazinesine ilave bir FAVÖK kârlılığı yaratılabilecekti. Ancak FAVÖK karından net kara doğru bir hesaplama yapıldığında ve işletmecilerin finansman ve yatırım maliyetleri dikkate alındığında net karlılıklar FAVÖK tutarına göre düşük kalacaktır. Yine örnekler incelendiğinde analizi yapılan havalimanlarında, yatırım tutarlarının düşük olduğu söylenebilecektir. Büyük tutarlı yatırım gerektiren havalimanlarında, kamu ortaklığı ve yatırımlara katılım devlet bütçesi üzerine yük getireceğinden doğru olmayabilecektir. Havalimanı dışındaki diğer köprü ve otoyol vb. yatırımlarda ise en ideal yöntem tutarların da büyük olduğu düşünüldüğünde kamu kesiminin içinde olmadiğ 1 ve tamamen özel sektörün işlettiği modeldir. 
Çalışmada verileri incelenen ve yatırım tutarları 75 ile 300 milyon arasında olan havalimanı yatırımlarında, kamunun işletmeciliğin içinde olması anlam kazanmaktadır. Kamunun \%20 veya başka bir oranda kamu hissesinin olması önerisi ile şirketlerinin karlılıklarından kamunun pay alması sağlanabilecek ve kamu bu şirketler üzerinde daha fazla kontrol gücünü elde edebilecektir.

Ayrıca görevli şirketlerin, şirket değerleri de bu süreçte ciddi artış göstermekte, kamu bu şirketlere ortak olarak şirketlerin değerlerinin artışından da menfaat elde edebilecektir. Değerlenen şirketlerde kamu kesiminin belli oranlarda ortaklıklarının olması ve ihtiyaç duyulduğu zamanlarda bu hisselerin bir kısmını veya tamamını satması durumunda ciddi gelirler elde edebileceği öngörülebilir.

$\mathrm{Bu}$ olumlu gelişmelerin yanında dünyada meydana gelen bazı küresel krizler, savaşlar ve salgın hastalıklar ilk olarak turizm sektörünü ve dolayısıyla ulaştırmanın en gözde türü olan havacılık sektörünü olumsuz olarak etkilemektedir. Şirketlerde bulunan kamu hissesi işletmeci diğer ortaklar için bir güvence olacaktır.

Özetle kamu özel ortaklığının, üst bir tanım olmaktan çıkıp gerçek bir ortaklık modeline dönüştürülmesi ile hem kamu hem de özel sektörün bu fiili ortaklık modelinden en üst seviyede faydalar sağlayacağı ve bu şekilde kurulan şirketlerin daha sağliklı temeller üzerinden yürüyeceği sonucu çıkarılabilir.

\section{KAYNAKLAR}

AIRBUS, (2016), Growing Horizons, 2017 / 2036.

Avşar T., (2012), Sivil Havacılık Sektöründeki Yap İşlet Devret Modeli Uygulamalarının Mali Açıdan İncelenmesi ve Değerlendirilmesi, Gazi Üniversitesi Sosyal Bilimler Enstitüsü Maliye Ana Bilim Dalı, Doktora Tezi.

Boing Company, (2016) Annual Report.

BoingCompany, (2015) Current Market Outlook 2016/2035.

DHMİ Genel Müdürlüğü, (2017), Faaliyet Raporu, Ankara.

DHMİ Genel Müdürlüğü, (2016), Faaliyet Raporu, Ankara.

DHMİ Genel Müdürlüğü, (2000), İstatistik Yı1lığı, Ankara.

DHMİ Genel Müdürlüğü, (2001), İstatistik Y1llığı, Ankara.

DHMİ Genel Müdürlüğü, (2002), İstatistik Y1llığı, Ankara.

DHMİ Genel Müdürlüğü, (2003), İstatistik Y1llığı, Ankara.

DHMİ Genel Müdürlüğü, (2004), İstatistik Y1llığı, Ankara.

DHMİ Genel Müdürlüğü, (2005), İstatistik Y1llığı, Ankara. 
DHMİ Genel Müdürlüğü, (2006), İstatistik Yıllı̆̆g, Ankara.

DHMİ Genel Müdürlüğü, (2007), İstatistik Yıllığı, Ankara.

DHMİ Genel Müdürlüğü, (2008), İstatistik Yıllı̆̆g, Ankara.

DHMİ Genel Müdürlüğü, (2009), İstatistik Yıllı̆̆ı, Ankara.

DHMİ Genel Müdürlüğü, (2010), İstatistik Yıllı̆̆ı, Ankara.

DHMİ Genel Müdürlüğü, (2011), İstatistik Yıllı̆̆ı, Ankara.

DHMİ Genel Müdürlüğü, (2012), İstatistik Yıllı̆̆g, Ankara.

DHMİ Genel Müdürlüğü, (2013), İstatistik Yıllı̆̆g, Ankara.

DHMİ Genel Müdürlüğü, (2014), İstatistik Yıllığı, Ankara.

DHMİ Genel Müdürlüğü, (2015), İstatistik Yıllı̆̆ı, Ankara.

DHMİ Genel Müdürlüğü, (2016), İstatistik Yıllı̆̆g, Ankara.

DHMİ Genel Müdürlüğü, (1998), İstatistik Yıllı̆̆g, Ankara.

DHMİ Genel Müdürlüğü, (1999), İstatistik Yıllığı, Ankara.

Emek U., (2009), Karşılaştırmalı Perspektiften Kamu Özel İşbirlikleri, Rekabet Dergisi, Say1:1, ss. 7.

Green Paper, (2004), Green Paper on Public-Private Partnerships and Community Law on Public Contracts and Concessions.

https://www.businessht.com.tr/piyasalar/haber/1721157-sabiha-gokcen-e-yuzde-40ortak-araniyor, 03/07/2018.

https://stats.oecd.org/glossary/detail.asp?ID=7315, (17/09/2018).

https://www.bloomberght.com/cds/turkiye-cds), (17/09/2018).

Malaysia Airports Holding Berhad, (2014), Faaliyet Raporu.

Malaysia Airports Holding Berhad, (2015), Faaliyet Raporu.

Malaysia Airports Holding Berhad, (2016), Faaliyet Raporu.

SSB, (2008), Uygulama Sözleşmesi, Ankara.

TAV Havalimanları, (2007), Faaliyet Raporu, İstanbul.

TAV Havalimanları, (2008), Faaliyet Raporu, İstanbul. 
TAV Havalimanları, (2009), Faaliyet Raporu, İstanbul.

TAV Havalimanları, (2010), Faaliyet Raporu, İstanbul.

TAV Havalimanları, (2011), Faaliyet Raporu, İstanbul.

TAV Havalimanları, (2012), Faaliyet Raporu, İstanbul.

TAV Havalimanları, (2013), Faaliyet Raporu, İstanbul

TAV Havalimanları, (2014), Faaliyet Raporu, İstanbul.

TAV Havalimanları, (2015), Faaliyet Raporu, İstanbul.

TAV Havalimanları, (2016), Faaliyet Raporu, İstanbul.

TAV Havalimanları, (2017), Faaliyet Raporu, İstanbul.

Wall, A. (2013), Public-Private Partnership in the USA: Lessons to Be Learned for the United Kingdom, Routledge, New York.

Yalçın F. C., (2014), Kamu Özel İş Birlikleri, Ankara Üniversitesi Sosyal Bilimler Enstitüsü Kamu Hukuku Ana Bilim Dalı, Doktora Tezi.

Yerlikaya G. K., (2002), Yap İşlet Devret Modeli Hukuki Mahiyeti ve Vergilendirme, Seçkin Yayıncılık, Ankara. 
